\title{
Digital platforms and tools used in the system of teaching English
}

\author{
V.V. Vonog ${ }^{1 *}, I . V$. Batunova $^{2}$, and V.V. Kolga ${ }^{3}$ \\ ${ }^{1}$ Siberian Federal University, Russia, Krasnoyarsk \\ ${ }^{2}$ Siberian Federal University, Russia, Krasnoyarsk \\ ${ }^{3}$ Reshetnev Siberian State University of Science and Technology, Russian, Krasnoyarsk
}

\begin{abstract}
Technogenic educational environment provided by means of Zoom, Skype, Webinar и Discord finds a wide application nowadays. The relevance of the paper is explained by new conditions and challenges faced by participants in the educational process in connection with the pandemic of the coronavirus infection Covid-19, which has reached a global scale. The new way of contact work and control of the educational environment revealed some problems. The purpose of this article is to identify significant, in the opinion of the authors, the digital platforms and tools used in the system of teaching English, to describe the advantages and disadvantages of the most popular of them from the point of view of teachers and students. According to the authors' point of view, such digital platforms as Zoom, Skype, Webinar и Discord are characterized by similar features including audio and visual contact, communication in chats, as well as opposing ones, e.g. limit of the free access, functions of video recording, waiting hall, calendar integration, etc. In the process of teaching English, cooperation and control obtain a personality-oriented nature, which results in increasing the motivation of students for independent and distance learning.
\end{abstract}

\section{A problem statement}

The topicality of the paper is explained by the necessity to turn to the tools of technogenic educational environment and treat the digitalization of education with greater responsibility caused by pandemic of coronavirus infection in 2020 [1]. The time has come for the digital transformation of education with the need to develop new ways to solve urgent problems [2]. The introduction of digital platforms leads to a wider application of Internet technologies and determined by «integration of social networks, electronic portfolios, massive online courses, interactive tasks, digital means of storing and selling material» in the educational environment, including the system of foreign language training [3]. Conducting an online lesson differs from teaching a lesson offline, and it is a mistake to believe that offline learning experience can be easily transferred to the Internet, even taking

\footnotetext{
*Corresponding author: vonog_vita@mail.ru
} 
into account the teacher's experience. Successful webinar delivery requires the digital competence of the teacher [4] and careful preparation [5]. Choosing a video conferencing platform suitable for teachers and learners' needs can be beneficial if the (dis)advantages and possibilities of that one have been presented. According to challenges that any teacher may face in terms of online classes, it would be appropriate to designate this thesis as a key problem of the study.

\subsection{The objective of the work}

According to authors' point of view, the system of teaching English integrates as range of didactic means, chosen by a teacher in connection with the goal of teaching a foreign language in a non-linguistic university, allow for systematic and methodological support of the educational process and «coordinate the course of training future specialists» [6]. Such a system proves its effectiveness in modeling and simulating real production situations in the educational environment [7]. Moreover, the system can change its tools resulting in adapting them to new conditions of interaction of all participants in the educational process. Digital platforms Zoom (https://zoom.us), Skype (www.skype.com), Webinar (https://webinar.ru), Discord (https://discord.com) have become very popular in the system of teaching English in connection with digitalization of educational environment as well as the pandemic of the coronavirus infection Covid-19, which has reached a global scale [810]. Implementation of work with these platforms is carried out in online version for browsers or in the application for smart phones and computers.

Interaction in real time with a large number of opportunities makes it popular among participants in the educational process. On the one hand, despite the similarity of a virtual lesson with a real one, the interactive aspects of communication online are formed with greater complexity due to distance and the absence of face-to-face contact. Maintaining interaction between the teacher and the student in a digital environment is an urgent problem, since the participants communicate at a distance. Communication is incomplete due to limited display of the communicator and video delay. The distance between users increases, which can lead to a lack of appropriate interaction and concentration on solving a specific situational problem. It is important for the teacher to control the involvement of students in the lesson, to be available to them, to assess the learning situation.

On the other hand, these digital platforms find wide application due to meeting needs of society in the implementation of communication in the educational process. Communication at these sites made it possible to some extent to imitate educational interaction, bringing it closer to the usual traditional by establishing audio and video contact. Online meetings in the format of webinars, video lectures and videoconferences have found application as an alternative to lectures, seminars and practical exercises [11]. Various forms of webinars, such as simple webinars, webinars in the panel discussion format and webinars with the involvement of a distant guest [1], allow solving many educational problems: from daily tasks to the tasks of final control. Taking into account a wide range of functional possibilities provided by digital platforms the authors aim at comparing them in terms of adaptation in teaching English and coping with problems the teachers may face.

\section{Results of the research}

Analysis of recent research devoted to the problems of pedagogical guidance, in particular to digitalization used in higher education, shows that growing attention is given to some aspects of learning a foreign language using computer technologies and digital platforms. It is necessary to pay special attention to the fact that competence-based approach 
implemented in the system of teaching English by means of "systematic integration into a holistic educational process through content, technologies and environmental factors" [5]. The key aspect that affects both the content and the technologies of education in the modern world is digitalization (English digitalization - the transition to a digital type of coding, which, however, is not just a technical process, but a sociocultural and anthropological one, among other things).

The study of using digital platforms and tools in teaching a foreign language is the subject of the research efforts of such Russian and foreign scientists as I.Yu. Konoreva, S.V. Titova, E.S. Polat, P.V. Sysoev, L.V. Shkerina, V.A. Shershneva, V.N. Sidorov, T.V. Sidorova, K.V. Safonov, I.B. Korotkina, E.V. Talalakina, K. Facer, Otto Peters, J. Watson, D. Whitelock et al [12-25].

Authors of the research paper "E-learning in Tertiary Education: Where Do we Stand?" refer E-learning to the use of information and communications technology (ICT) to enhance and/or support learning in tertiary education. It covers a wide range of systems, from students using e-mail and accessing course work online while following a course on campus to programmes offered entirely online.

Otto Peters in his investigation "Digital Learning Environments: New Possibilities and Opportunities" (International Review of Research in Open and Distance Learning Vol. 1, №. 1 (June 2000) convinces that "Tertiary education institutions generally feel that elearning has a broadly positive effect on the quality of teaching and learning, although few have been able to offer detailed evidence. There is much indirect evidence, including student satisfaction surveys, but these may not be enough to offset the prevalent doubt about the pedagogic value of online learning among students and academics. Digital learning environments open up new opportunities and chances not only for heteronymous but also for autonomous learning".

The issue of digital storage of an unlimited amount of authentic information is discussed by Watson (2008). Special attention is paid to increasing the autonomy and independent work of the student when working with hypertext and web pages (Titova, 2017; Sysoyev et al., 2015; Whitelock, 2008).

There are some papers where authors identify problems, propose teaching methods, and assess the advantages and disadvantages in the context of digitalization. For example, Yu. I. Davydenko in the article "Teaching autonomous reading in a foreign language at a technical university: criteria for selecting text material". (Proceedings of BSTU. Series 4: Print and Media Technologies 2017) identifies the problems that hinder the effective teaching of a foreign language and suggests ways to solve them by creating an information and communication learning environment for learning.

The role of increasing students' interest and motivation in learning foreign languages through a variety of digital platforms, different from traditional ones, is studied by Polat (2010) and Shershneva et al. (2016).

The increased interest in the capabilities of digital tools pushed developers to expand the functionality, which has a positive impact on the technological qualities at the moment. Let's consider and compare the functionality of Zoom, Skype, Webinar, Discord.

All of these tools provide audio and video contact, which, in relation to teaching English, contributes to two-way communication, as well as being participants in dialogues and polylogs, asking questions, conducting disputes, organizing discussions, etc. The ability to establish visual contact allows you to read non-verbal signals and simulate as much as possible live communication, characteristic of face-to-face classes, which teachers get used to.

Unfortunately, there is a problem that many teachers have faced, namely, the lack of possibility and wish of students to turn on the camera during class. On the one hand, this can be explained by technical difficulties, since most of the students use the mobile 
Internet, i.e. you can either turn on the video or read the text located on the screen. The latter is often preferable for the educational process. On the other hand, the ability to not turn on the camera means a more comfortable environment for students, especially if the home environment does not have the ability to share the background with all participants in the online meeting. In January 2021, a survey of 68 students of School of Engineering and Construction of Siberian Federal University showed that $81 \%$ of respondents turn on the camera in the classroom only at the request of the teacher, one student always turns on and one student never turns on.

The identified problem prompts the search for other ways of expressing a response. Zoom, Skype, Webinar and Discord enable interactive gesture substitutions to express approval or other emotion, which is especially important when learning a foreign language. The raised hand gesture symbolizes the student's readiness to answer the question. The thumbs up gesture indicate agreement or acts as approval. It is noteworthy that this functionality appeared on the Webinar.ru platform only in 2020 [26].

Using a chat is another important feature of these digital tools. Chats serve as a platform for written communication in a foreign language, allow you to conduct diagnostic surveys, receive quick feedback individually or in a group, and also check the involvement of students in the educational process.

Screen sharing lets you share your desktop, documents, tutorials, browser tabs, etc. This is especially important when paper handouts cannot be used. Screen sharing allows the student to share materials they are currently working on with the teacher or other students, as well as demonstrate a project presentation. In response, the student has the opportunity to receive quick feedback, comments and feedback on the project $[27,28]$.

In terms of lesson planning these platforms allows us to plan our online lesson in advance. Thus, they act not only as a video broadcasting platform but as a calendar as well. Scheduling classes in a calendar allows the teacher to keep a log of upcoming events and promptly remind students of the next lesson.

When working in a virtual classroom, the teacher's role expands. He doesn't act as a teacher, he acts as a moderator of the online class. Each lesson-event has a closed format, which means that it is necessary to obtain an individual code and a videoconference password before the lesson. Each potential student's participation is approved by the teacher. Such a system duplicates the educational process in real time and does not allow third parties to attend the lesson, keeping the privacy and the course of the lesson like an offline lesson.

Besides above mentioned tools in the form of screen broadcast and whiteboard, the platforms provide conference participants with such creative tools as audio streaming. Due to this tool students can complete listening assignments. A more creative tool is to use an alternative background during the conference. With the help of the participants' background replacement tool, the teacher can give students tasks to speculate the situation, where the background plays an additional role and allows students to be involved in the work more actively.

Let us turn to the aspects that are unique for individual tools of the foreign language training system (see Table 1).

According to the results of the study by the authors, Zoom and Webinar.ru are the most convenient platforms in comparison with Skype and Discord for the interaction of all participants in the educational process within the framework of the foreign language training system. A number of authors also support the popularity of Zoom on the basis of the sociological study "Opinion of students of Russian universities on forced distance learning", conducted in May - June 2020 [29]. 
Table 1. Comparison of Zoom, Skype, Webinar and Discord functionality.

\begin{tabular}{|c|c|c|c|c|}
\hline $\begin{array}{l}\text { Digital tool } \\
\text { functionality }\end{array}$ & Zoom & Skype & Webinar.ru & Discord \\
\hline $\begin{array}{l}\text { Free access } \\
\text { (by time and } \\
\text { number of } \\
\text { participants) }\end{array}$ & $\begin{array}{l}40 \text { minutes in } \\
\text { the free version, } \\
\text { the number of } \\
\text { participants is } \\
\text { not more than } \\
100 \text { people }\end{array}$ & $\begin{array}{l}\text { There is no time } \\
\text { limit, but the } \\
\text { recommended } \\
\text { number of } \\
\text { participants is } \\
\text { no more than } 25 \\
\text { people }\end{array}$ & $\begin{array}{l}\text { There is no time } \\
\text { limit, but the } \\
\text { number of } \\
\text { participants in } \\
\text { the free version } \\
\text { is no more than } \\
5 \text { people }\end{array}$ & $\begin{array}{l}\text { There is no } \\
\text { time limit or } \\
\text { the number of } \\
\text { participants }\end{array}$ \\
\hline $\begin{array}{l}\text { Video recording } \\
\text { possibility }\end{array}$ & $\begin{array}{l}\text { Any participant } \\
\text { can record }\end{array}$ & $\begin{array}{l}\text { Any participant } \\
\text { can record }\end{array}$ & $\begin{array}{l}\text { The recording is } \\
\text { made } \\
\text { automatically by } \\
\text { the organizer }\end{array}$ & Not available \\
\hline Technical support & Not available & Not available & Available & Not available \\
\hline $\begin{array}{l}\text { The possibility to } \\
\text { divide into session } \\
\text { rooms or their } \\
\text { analogs }\end{array}$ & Available & Not available & Available & Available \\
\hline $\begin{array}{l}\text { The possibility to } \\
\text { limit } \\
\text { communication in } \\
\text { chat }\end{array}$ & $\begin{array}{l}\text { Available. } \\
\text { Possible ways of } \\
\text { interaction: all } \\
\text { students to all } \\
\text { students, all } \\
\text { students to the } \\
\text { organizer }\end{array}$ & Not available & $\begin{array}{l}\text { Available. } \\
\text { Possible ways of } \\
\text { interaction: all } \\
\text { students to all } \\
\text { students }\end{array}$ & Not available \\
\hline $\begin{array}{l}\text { A waiting room } \\
\text { for students } \\
\text { wishing to join the } \\
\text { video meeting }\end{array}$ & Available & Not available & Available & Not available \\
\hline $\begin{array}{l}\text { The necessity to } \\
\text { install platform } \\
\text { label on the user's } \\
\text { device }\end{array}$ & Available & Available & Not available & Available \\
\hline $\begin{array}{l}\text { Lesson planning } \\
\text { integrated with } \\
\text { calendar }\end{array}$ & Available & Not available & Available & Not available \\
\hline
\end{tabular}

The functionality of Zoom and Webinar.ru includes a wider range, including the possibility of scheduling classes. Let us add that Zoom and Webinar.ru are not only video broadcasting platforms, but are also a calendar for its participants: the teacher keeps a log of upcoming events, and the platform reminds students in a timely manner about the next lesson. During online interaction, the teacher simultaneously acts as a moderator and administrator. Each lesson has a closed format, which involves obtaining an individual code and password for a video conference before a foreign language lesson. The participation of each potential student is approved by the administrator-teacher. Such a system duplicates the educational process in real time and does not allow third parties to attend the lesson, keeping the privacy and the course of the lesson like an offline lesson [30-32].

The ability to record video, as well as work in separate session rooms, are other similar characteristics of Zoom and Webinar.ru. With the help of the Session Rooms tool, the teacher provides interactivity and feedback of interaction with students, which can become an additional incentive to optimize students' independent work. Thanks to the cooperation 
of the teacher and students, there is the possibility of assessment and self-assessment in pairs and small groups. Moreover, such interaction provides an individual approach to teaching a foreign language and allows you to receive feedback from a teacher, student or group of students, contributing to the choice of correct answers and solutions.

Among the differences between Zoom and Webinar.ru, one can note the need to install a program or application on the user's device and limit free access and the number of participants in the video conference in the free version. Therefore, depending on the format of the intermediate or final certification, as well as the number of its participants, the teacher himself determines the most suitable mode and online platform for interacting with students.

The increased interest in the capabilities of digital tools pushed developers to expand the functionality, which has a positive impact on the technological qualities at the moment. According to analyze of presented tools in Table 1 used in the system of teaching English, we underline the following advantages:

free access to teaching materials both obligatory (within obligatory teaching minimum) and optional ones, e.g. audio and video, moreover, all teaching materials are available anywhere, at any time;

- a possibility of the constant interaction and experience exchange with other students and a full time classroom teacher;

- $\quad$ portability, it being the principal advantage, because almost all personal electronic devices are compact, light and available, they enable students to make notes and enter any data in a device directly;

- a personal device increases students' incentive because they are keen on different gadgets and use them constantly;

- $\quad$ students can approach their teacher outside the classroom;

- $\quad$ students can work at their own pace.

However, we cannot help but noticing some drawbacks, mainly concerning platforms maintenance:

- $\quad$ the resolution of a personal device screen (it can be low);

- the impossibility of continuous work in the platform because of rapid discharging of a device;

- $\quad$ the lack of software power to enclose some teaching materials;

- the Internet problems connected with its access, including restrictions which a provider gives for the mobile communication.

To sum up, in spite of a number of advantages and disadvantages of digital platforms and tools, they provide a range of functional possibilities that meet requirements in terms of the system of teaching English. Using digital platforms and tools make it possible to integrate audio and video contact for all participants of educational process and support such activities as dialogues, asking questions, conducting disputes, organizing discussions. The teacher acts as a moderator of online classes, which simulate as much as possible live communication, thus contributing to classes interaction productivity and effectiveness.

\section{Conclusions}

In conclusion we'd like to underline that the educational process in the system of teaching English can be carried out by means of such digital platforms as Zoom, Skype, Webinar and Discord effectively.

On the one hand, these platforms have a number of similar features, including the possibility of audio and video communication, chatting, screen sharing and the use of interactive gestures. On the other hand, they differ in a number of positions, namely, the need to install the program / application on the user's device, the restriction of free access, 
the possibility of video recording, the presence of a waiting room, the ability to work in separate session rooms and integration with the calendar. Undoubtedly, the choice of a specific tool will be determined by the technical and financial possibilities of the educational institution, as well as teacher's goals and experience.

Moreover, digital platforms for providing online communication in audio and video way in a technogenic educational environment support the educational process. By imitating live communication, Zoom, Skype, Webinar and Discord allow us to implement English learning as close as possible to the traditional way, providing participants with support and a variety of forms of feedback from the teacher and other students, regardless of geographic position. Classes in a technogenic educational environment based on digital platforms and tools support the systematic and methodological assistance of the educational process, including interaction and students' results monitoring which makes it possible to register indicators of students' progress in terms of a learner-centered approach in the system of teaching English.

\section{References}

1. V.V. Vonog, I.V. Kharlamenko, V.V. Kolga, Video conference tools as an element of technogenic educational environment in the system of foreign language teaching, Informatika i obrazovanie, 1(320), 57-62 (2021)

2. V.V. Vonog, I.V. Batunova N.V. Baturina, A.A. Struzik, Productive Assessment Used as Important Means of Technogenic Society Development, Studies in Systems, Decision and Control, 314, 1099-1109 (2021)

3. V.V. Vonog, Guidance on developing a professional through information technologies in teaching a foreign language, Vestnik MSLU, 6(814), 41-52 (2018)

4. I.V. Batunova, E.I. Lobyneva, Al.Yu. Nikolaeva, N.V. Baturina, Teaching IT Specialists with the Help of Online Learning Society Development, Studies in Systems, Decision and Control, 314, 1091-1098 (2021)

5. T.V. Bugaychuk, Concept of Adults' Socialization by Means of Further Professional Education, Yaroslavl pedagogical bulletin, 1, 131-135 (2016)

6. V.V. Kol'ga, M.A. Shuvalova, Training aerospace technicians in a dual education, 216 (Krasnoyarsk: Krasnoyar. Pedagogical university of V.P. Astafev, 2019)

7. M.V. Noskov, Once again about informatization of education as a scientific specialty, Materials of the III International conference. Siberian Federal University, 2, 262-266 (2019)

8. K. Facer, Taking the 21st century seriously: young people, education and sociotechnical futures, Oxford Review of Education, 38(1), 97-113 (2012)

9. S.D. Kalinina, Webinar as a form of e-learning in higher education, Bulletin of MGIMO University, 2(41), 291-295 (2015)

10. N.N. Bykova, Interactive training of teachers for webinars and video lectures, Man and Education, 1(58), 86-91 (2019)

11. P.D. Rabinovich, K.E. Zavedenskiy, M.E. Kushnir, Yu.E. Khramov, A.R. MelikParsadanov, Digital transformation of education: from changing funds to developing activities, Informatika i obrazovanie, 5, 4-14 (2020)

12. S.V. Titova, The model of mobile teaching foreign language, Pedagogics and Psychology of Education, 1, 123-133 (2017) 
13. D. Whitelock, Activating Assessment for Learning: are we on the way with Web 2.0? In Web 2.0-Based-E-Learning, Applying Social Informatics for Tertiary Teaching, 319-342 (2010)

14. J. Watson, Blended learning: The convergence of online and face-to-face education, In North American Council for Online Learning, 16 (2008)

15. I.Yu. Konoreva, Working with professionally oriented text in the process of foreign language teaching at non-linguistic institutes, Fire safety: problems and prospects, $\mathbf{8}$ (2017)

16. E.S. Polat, The problem of determining the effectiveness of distance learning, Otkrytoe obrazovanie, 3 (2005)

17. P.V. Sysoev, The use of new educational Internet technologies in teaching a foreign language (based on the material of US cultural studies), Vestnik TGU, 2 (2008)

18. L.V. Shkerina, T.A. Shkerina, New didactic principles of theoretical training of students, Bulletin of KSPU im. V.P. Astafieva, 3(41) (2017)

19. V.A. Shershneva, Yu.Vl. Vainshtein, T.O. Kochetkova, Adaptive learning system in an electronic environment, Program systems: theory and applications, 4(39) (2018)

20. V. N. Sidorov, T.V. Sidorova, Contemporary Didactics in Higher Education in Russia, European journal of contemporary education, 3(17), 357-367 (2016)

21. I.B. Korotkina, Literacy of the scientific text: conceptual differences between Russia and the West and their consequences, Scientific periodicals: problems and solutions, 2(20) (2014)

22. K.V. Safonov, The syntactic analysis of context-free languages, Reshetnevskie readings, 21-2 (2017)

23. E.V. Talalakina, V.V. Radaev, S.Al. Medvedev, Five main challenges in teaching, Education Issues, 1 (2018)

24. K. Facer, The Myth of the "Cyberkind": Young People at the Margins of the Information Revolution, Journal of Youth Studies, 4, 451-469 (2011)

25. O. Peters, Environmental contributions to obesity epidemic, Science, 2, 1371-1374 (2010)

26. I.A. Aleshkovsky, A.T. Gasparishvili, O.V. Krukhmaleva, N.P. Narbut, N.Ye. Savina, Students of Russian universities on distance learning: assessment and opportunities, Higher education in Russia, 10, 86-100 (2020)

27. A.V. Gureeva, E.F. Valyaeva, The practice of using Zoom in the process of distance learning a foreign language, Modern pedagogical education, 6, 47-50 (2020)

28. T.E. Vedenskaya, The concept of "System" and a systematic approach in pedagogy, Theory and practice of social development, 7, 197-199 (2015)

29. B. Tomlinson, Materials development for language learning and teaching, Language teaching. Cambridge: Cambridge University Press, 45, 143-179 (2012)

30. D. Whitelock, S. Watt, Reframing e-assessment: adopting new media and adapting old frameworks, Learning, Media and Technology, 33, 151-154 (2008)

31. L.G. Viktorova, About pedagogical systems, Krasnoyarsk, 101 (Krasnoyar. Pedagogical university of V.P. Astafev, 1989)

32. D.A. Mezentseva, E.S. Dzhavlakh, O.V. Eliseeva, A.Sh. Bagautdinova, On the Question of Pedagogical Digital Competence, Higher education in Russia, 29, 88-97 (2020) 